\title{
Migration and Trade Union Rights ${ }^{\mathrm{a}}$
}

\author{
Thierry Baudasséb and Rémi Bazillier ${ }^{c}$
}

JEL-Classification: F22, J51, J61, J83

Keywords: migration, core labor standards, freedom of association and collective bargaining

\section{Introduction}

In 2006, 4 millions of permanent migrants entered OECD countries (OECD, 2008). It represents an increase of $5 \%$ compared to the previous year. In average, immigrants counted for $12 \%$ of the whole population in OECD countries. Since 2000, the increase is very high in some countries: 66\% in Ireland, 40\% in Finland and 34\% in Austria. Political debates on these issues are very sensitive and relatively new in some countries which were emigration countries and became immigration countries in the last years. On the other side, emigration represents a huge challenge for developing countries. In some countries, for example in Caribbean islands, more than $40 \%$ of the working force lives abroad (DEFOoRT 2008). The problem is more accurate for educated workers with emigration rates over $70 \%$ ( $85 \%$ in Jamaica). Challenge is huge both for destination and origin countries. In immigration countries, the integration of migrants into local labor markets is a real concern. In source countries, governments may be concerned by brain drain and its consequences on general human capital accumulation.

Thus the understanding of migration determinants is a central point for decision makers. In particular, wages and labor market characteristics are of particular interest. Migration may be influenced by economic or social characteristics in source and destination countries. We may distinguish push factors from pull factors. The conventional wisdom considers that migrants are attracted by generous social welfare, high wages or good working conditions. However, labor markets characteristics in source countries do not have to be neglected. This paper addresses the influence of labor standards in origin countries on emigration rates.

a We would like to thank Tobias Müller, Sivio Tai and participants at the SSES annual meeting. All remaining errors are obviously ours.

b LEO-CNRS (UMR 6221), Université d'Orléans. thierry.baudasse@univ-orleans.fr.

c LEO-CNRS (UMR 6221), Université d'Orléans. remi.bazillier@univ-orleans.fr. 
More precisely, out of the four core labor standards ${ }^{1}$ recognized by ILO (1998), freedom of association and collective bargaining rights potentially have one of the largest effects. We propose to see how working conditions in origin countries may influence the decision to migrate.

The economic literature on migration deals with two main questions. The first one is the determinants of labor migration. This tradition comes from Нicks (1932) who argued that the main determinant of migration is the difference of wages. Todaro (1969) and Harris and Todaro (1970) observed that even in the presence of urban unemployment, migration is still an attractive option if the agents maximize their expected earnings. Field (1975) and Gupta (1993) introduced an informal sector into this framework. The "new economics of migration" proposes new possible determinants of migration. For example, movement of workers can be a risk diversification strategy inside the household. According to this approach, income of migrants, which is not correlated with agricultural income, will reduce the risk for the household (LEVHARI AND STARK, 1982; LUCAS and Stark, 1985; STARK, 1991). Another useful hypothesis introduced by new economics of migration is that individuals are not migrating only in response of absolute income differential but also according to relative deprivations (STARK and Yitzhaki, 1988; Stark and Taylor, 1991; Stark, 1991).

The second main question is the consequences of migration. One major issue is the influence of workers migration on the labor market in destination countries (see for example Grossman, 1982; Borjas, 1994; 1999; Borjas, Freeman and KaTZ, 1997). Another important issue is the influence of migration on the accumulation of human capital in source countries. This concern began with Bhagwati and Dellafar (1973) and Bhagwati and Hamada (1974), who argued that migration may have negative consequences in developing countries because of the deprivation of their best-trained workers (phenomenon of brain drain). Nevertheless, more recent models (Beine, Docquier, and Rapoport, 2001; 2003; Mountford, 1997; Stark, Helmenstein and Prskawetz, 1997) show brain drain may have positive consequences, through increased incentives to accumulate human capital in developing countries. Brain drain may become a brain gain. Finally, some authors have questioned the effects of migration on social capital in destination countries as well as in source countries (ScHIFF, 1999; 2002).

1 Freedom of association and collective bargaining, elimination of child labour, forced labour and discrimination. 
Interactions between labor markets have been studied in many different ways but focused on two main specific aspects: the role of wages differential and the consequences of migration on labor markets in destination countries. So far, very few studies focus on the influence of labor market characteristics in source countries. In parallel, a controversial debate emerged concerning the development outcomes of labor standards. The empirical literature on this topic established the ambiguous links between labor standards and international trade (BROwn, 2000; Granger, 2005), foreign direct investment (Kucera, 2002), economic coordination (Aidt and Tzannatos, 2002), productivity (Brown, Deardorff, and Stern, 1996; Maskus, 1997; OCDE, 1996), long-term per capita income (Bazillier, 2008) and income inequalities (Bazillier and Sirven, 2008). Most of these outcomes may influence the determinants of emigration. Lastly, the extent of informal economy matters regarding the economic consequences of trade union rights and migration. Calvo (1978) introduced trade unions in the Harris and TODARo (1970) framework where the rural-urban migration depends on the wage-setting influenced by trade unions. Quibria (1988) introduced explicitly the informal urban sector in such framework. HARRISON and LEAMER (1997) showed that restrictive labor standards may induce a shift of a significant part of the working force from the formal to the informal sector. SINGH and Zамміт (2000) considered that freedom of association may increase the level of informality through the fall of formal employment and labor demand in this sector. Empirically, the influence of labor standards on informality is not clear. Marques and Pages (1998) found a high correlation while Kucera and Galli (2004) showed that countries with higher standards in Latin America tend also to have a higher share of formal employment.

This paper proposes to study the influence of freedom of association and collective bargaining rights ${ }^{2}$ on migration in source countries. The first contribution of this paper is the modeling of the possible effects of collective bargaining on emigration rates. Collective bargaining is alternatively modeled as (1) an income transfer from the high-skilled workers to the low-skilled and, (2) a premium for workers in the formal sector. The second contribution of the paper is the building of an original measurement of freedom of association and collective bargaining right, for a large panel of countries. The third contribution is the empirical

2 Freedom of association and collective bargaining rights are considered as equivalent. The recognition of these rights is included in the same ILO conventions (87 and 98). Freedom of association, collective bargaining and trade union rights will be understood similarly. No distinctions will be made between the use of the three terminologies. 
analysis of such linkages. Globally, we find a negative impact of freedom of association on emigration rates for high-skilled workers and low-skilled workers.

The paper is organized as follow. The second section proposes different theoretical modeling of the effects of collective bargaining on migration flows. The third section deals with the empirical measurement of freedom of association and collective bargaining rights. Fourth section deals with the econometric analysis of their effects on migration. A fifth section proposes a complementary analysis dealing with the influence of social tensions on migration. Finally, last section concludes.

\section{Theoretical Frameworks}

\subsection{Presentation of Complementary Models}

We may suppose that collective bargaining will induce an improvement of wages and working conditions for workers at the bottom of the pay scale ${ }^{3}$. However, if this right is only respected in the formal sector, workers with the lowest productivity may not benefit from these collective rights if they are excluded from this sector ${ }^{4}$. We will thus propose two complementary modeling of these effects. First, collective bargaining rights will be modeled as redistribution from highskilled to low skilled workers. In order to raise wages of low skilled workers, firms will reduce the relative wages of the high-skilled workers in order to maintain their level of profit (otherwise, the capital will fly outside the country). A second option could be the following one: the improvement of working conditions in the formal sector will increase the size of the informal sector where these rights are not respected (Harrison and Leamer, 1997). High-skilled workers will move to the formal sector which will employ workers with the highest productivity. Low-skilled workers will not benefit from this right and the winners will be high-skilled workers.

We will then have two possible models: a model where collective bargaining is modeled as a transfer from high-skilled to low-skilled workers (model a) and a model where collective bargaining is a premium for workers in the formal sector,

3 According to SAINT PaUl (2002), unskilled workers are often more unionized and benefit more from labor market institutions.

4 See the literature on "insiders" and "outsiders" theories (LINDBECK and SNOwER, 2001, for an overview). 
with no change in the informal sector (model b). Empirical analysis will be used to validate or refute each of them.

\subsection{Collective Bargaining as a Transfer from High-Skilled to Low-Skilled Workers}

We consider two countries $S$ and N (respectively the South and the North). In each country, population is standardized to 1 . There exist in these two countries two categories of workers: skilled (index $q$ ) and unskilled (index $n q$ ). The proportion of skilled workers in the north is $\alpha$ and in the South is $\beta$, it is supposed that $\alpha>\beta$. In the North the production function is:

$$
Y=A_{1} L_{q}+A_{2} L_{n q} \text { with } A_{1}>A_{2} .
$$

And in the South it is:

$$
Y=B_{1} L_{q}+B_{2} L_{n q} \text { with } B_{1}>B_{2} .
$$

We suppose that labor standards are perfectly respected in the North ${ }^{5}$ and/or we are under perfect competition. Wages, $\mathrm{w}$, are established as follow:

$$
\begin{gathered}
w^{q}=A_{1}, \\
w^{n q}=A_{2} .
\end{gathered}
$$

In the South, labor market is characterized by imperfect competition. Employers have a market power over unskilled workers. This market power is equivalent to redistribution from unskilled to skilled workers. We assume that the lack of freedom of association creates a situation of monopsony on the labor market (OECD, 1996; 2000). The enforcement of labor standards will then compensate this distortion on the labor market.

Skilled workers are in proportion $\beta$, so a dollar taken from an unskilled worker ends in $(1-\beta) / \beta$ additional dollar for each skilled worker.

5 Of course, this is a strong assumption. However, as we focus on the influence of trade union rights in the sending country, we consider it is not a problem in our case. 
There are two different wages in the south:

$$
\begin{gathered}
v^{q}=B_{1}+\frac{1-\beta}{\beta} t_{1}, \\
v^{n q}=B_{2}-t_{1} .
\end{gathered}
$$

$t_{1}$ is the transfer from unskilled to skilled workers. It reflects the level of freedom of association enforced in the country. The closer to zero is the value of $t_{1}$, the higher is the enforcement of such right. So, diminishing the value of $t_{1}$ gives us what we formerly call formally "model a".

Individuals in the South are characterized by a certain level of migration cost, depending on their educational level: $c_{i}(k)$ with $k=(q, n q)$. This cost is supposed to depend on the psychological capacity to support distance with friends and family, the existence of migrants' network abroad, the individual taste for mobility. Parameter $c_{i}$ in each category of workers is distributed according to a uniform distribution between 0 and one maximum value $C^{*}(k)$ with $k=(q, n q)$.

Individuals decide to migrate when:

$$
w^{k} \geq v^{k}+c_{i} \text {, that is, when } w^{k}-v^{k} \geq c_{i} .
$$

They migrate when the cost of migration is lower than wage differential between north and south. For a given value of the parameters, there will exist a proportion of the population of the category equal to $\left(w^{k}-v^{k}\right) / C^{*}(k)$ such that this proportion of the population is willing to migrate.

By decreasing $t_{1}$ one decreases $v^{q}$ and thus one increases $w^{q}-v^{q}$ and $\left(w^{q}-v^{q}\right) / C^{*}(q)$. In other words one increases the proportion of skilled workers who wish to migrate. On the other hand, one increases $v^{n q}$ and thus one decreases the proportion of unskilled who want to migrate.

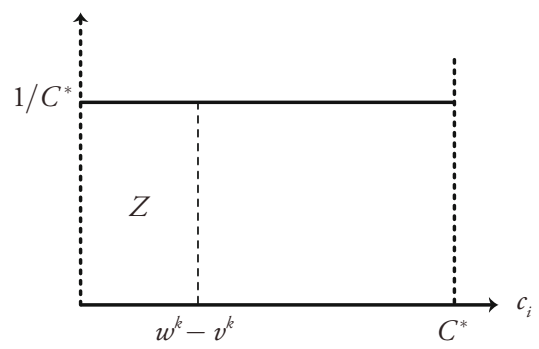


Proposition 1: If collective bargaining rights are respected in all sectors and if wages only depend on skill levels, the enforcement of such rights will increase the number of skilled migrants and will lower the number of unskilled migrants.

The proportion of each population wishing to migrate is then defined by the following table:

\begin{tabular}{ll}
\hline Qualified & Not-qualified \\
\hline$F / C^{*}(q)$ with $F=A_{1}-B_{1}-(1-\beta) / \beta \cdot t_{1}$ & $G / C^{*}(n q)$ with $\mathrm{G}=A_{2}-B_{2}+t_{1}$ \\
\hline
\end{tabular}

Notice that an alternative model would be the following. In absence of collective bargaining, unskilled workers are paid below their productivity $\left(v^{n q}=B_{2}-t_{1}\right)$ while skilled workers are paid at the level of their marginal productivity (without wage premium as stated before). Here, the transfer $t_{1}$ would be a rent for owners of firms. In this alternative model, collective bargaining leads to a decrease in the number of unskilled migrants inasmuch as their income is higher than in absence of trade union rights. However, number of skilled migrants would remain unchanged.

Proposition 1bis: In a model similar to the one of Proposition 1, when there is no wage premium for the skilled in absence of collective bargaining rights, the enforcement of such rights will lower the number of unskilled migrants but will remain the number of skilled migrants unchanged.

\subsection{Collective Bargaining as a Premium for the Formal Sector (Model b)}

We now have two sectors: the informal and the formal sectors. Each worker is characterized by a level of qualification $q_{i}$. These levels $q_{i}$ are distributed according to a uniform distribution between 0 and a maximum value $Q$. Formal sector attracts skilled workers because of better wages and working conditions. Firms from the formal sector can choose the most productive workers and then hire the most qualified. Other workers work in the informal sector. In order to simplify, we assume that wages in the formal sector are equal to the sum of a minimum institutional real wage $\mathrm{w}$ and a premium which depends on the qualification of the employee: $w\left(q_{i}\right)=w+p\left(q_{i}\right)$, with $p(0)=0$ and $\mathrm{p}^{\prime}\left(q_{i}\right)>0$. The result of collective bargaining is a rise of the minimum wage $w$. We also assume that the formal sector produces an internationally tradable good which price is determined by the international price. Income in the informal sector is supposed to be equal to 
$s<w$. We assume that informal sector produces a service. The economy is then composed by two goods: the tradable good produced by the formal sector and the service produced by the informal one.

When w raises all wages in formal sector raise and consequently the marginal cost of the good raises for a given produced quantity. Maximization of profit implies that the price of the good (internationally fixed) is equal to the marginal cost so, in order to maximize profit, the formal sector will shrink its production and employment. So, we have:

$L_{f}=f(w)$ with $f^{\prime}<0, L_{f}$ being the employment in formal sector. A rise in $w$ will then imply a fall in formal employment $L_{f}$. The formal sector will then select more strictly its employees, hiring the individuals with a level of qualification higher than $q_{i}^{*}$, in order to have:

$L_{f} / L=\left(Q-q_{i}^{*}\right) / Q$, with $L$ the total employment, equal to the total population which is constant. By hypothesis, there is no unemployment, the informal sector being able to hire the population not employed in formal sector with a wage $s$.

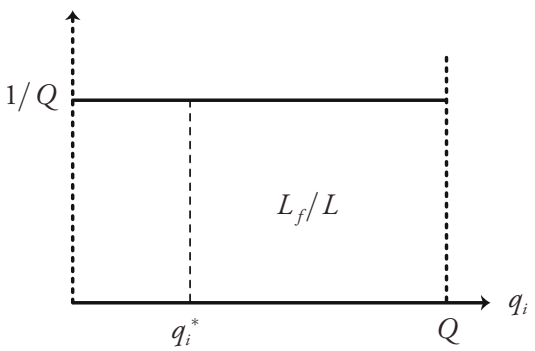

Obviously, when $L_{f}$ decreases, the minimum level of qualification $q_{i}^{*}$ needed to be hired in the formal sector rises. The increase of the minimum wage w, which is here a consequence of collective bargaining, induces a higher selectivity in the formal sector. In summary, in this framework, only skilled workers will benefit from this labor standard. It can possibly have negative consequences for unskilled workers if they are fired from the formal sector. Collective bargaining will then increase the income of all skilled workers and it may decrease the income of some unskilled. This will lead to less migration among skilled workers and it may lead to more migration among the unskilled. 
Proposition 2: If collective bargaining rights are only enforced in the formal sector and if the wages depend crucially on the sector of employment, the enforcement of such rights will lower the migration of skilled workers and possibly increase the migration of the unskilled.

\section{Measurement of Trade Union Rights}

Different measures exist in order to estimate a level of freedom of association. These indexes can be classified into two main categories: legal or outcome indexes.

Legal indexes observe legal protection of trade union rights. One limit of this family of indexes is that it gives no information about the effectiveness of these rights. Even if freedom of association is a constitutional right, there is no guarantee that this right is enforced in practice. On the other side, a country without legal protection may face large activities of trade unions or collective bargaining. In this category of indexes, we have Botero, Djankov, La Porta, and LopezDe-SiLANes (2004) indexes on labor union power and collective bargaining.

Outcome indexes are based on the consequences of freedom of association on the number or proportion of workers that belong to an organization related to labor issues (GHAI, 2003). "In general, the higher the union density is, the stronger the defense of workers interests in negotiations with employers and the government, and the greater the participation by workers in matters affecting their work". However, there are different problems. Unionization rate is also based on historical traditions or political systems (Jose, 2002). GHAI (2003) also argues it is a problem for developing countries because of the small size of the labor force in the formal economy. Moreover, a high unionization rate does not reflect necessarily a good level of freedom of association if the membership to a trade union is compulsory, strongly recommended, or needed to get access to some jobs. Activities of trade unions can be strong where unionization rate is low (like in France). We will then take into consideration other outcome variables such as the number of strikes or proportion of workers involved. Lastly, the number of strikes reflects both trade unions activities but also the level of social tensions in the country.

Here, we choose to aggregate different categories of indexes measuring both legal protections and effective enforcement of trade union rights. Our first index index_TU aggregates the number of strikes per year, the number of workers involved in trade unions activities (in \% of the working force), the index civil rights, from Freedom House measuring among other things the effective level of 
trade union rights, and an index proposed by BотERo et al. (2004), index_col_ barg13, which measures the statutory protection and power of union ${ }^{6}$. In a first time, we do not propose to include the unionization rate into this index because of the limited number of countries where this information is available. We will however present in a second time different alternative indexes to check the robustness of our results. The index is obtained using principal component analysis (PCA), which goal is to isolate common factors between different variables (here the effective trade union rights), by reducing total information in order to get an easier economic description of the variables. Table 1 gives the results of this PCA.

Table 1: PCA Results for index_TU

\begin{tabular}{lcccc}
\hline Component & Eigenvalue & Difference & Proportion & Cumulative \\
\hline Factor 1 & 1.31421 & 0.329148 & 0.3286 & 0.3286 \\
Factor 2 & 0.985065 & 0.0481961 & 0.2463 & 0.5748 \\
Factor 3 & 0.936869 & 0.173017 & 0.2342 & 0.8090 \\
Factor 4 & 0.763853 & & 0.1910 & 1 \\
\hline
\end{tabular}

A criterion frequently chosen to decide how many factors to retain is the Kaiser criteria. According to this criterion, if a factor explains more than the original variable, it is necessary to extract it. As the sum of eigenvalues of $p$ variables is equal to $p$, we only retain factors which have an eigenvalue higher than 1 . According to this criterion, only the first factor would be sufficient to get a satisfactory description of the data. However, we could notice that the second and the third factor has also a significant explicative power and an eigenvalue very close to one. This result reinforces the idea that trade union rights are a very complex phenomenon, difficult to measure and to describe. Our explanation is that one single information (for example a high proportion of workers involved) may reflect two things. First, it may mean that trade union rights are well-respected.

6 It measures the statutory protection and power of unions as the average of the following seven dummy variables which equal one: (1) if employees have the right to unionize; (2) if employees have the right to collective bargaining; (3) if employees have the legal duty to bargain with unions; (4) if collective contracts are extended to third parties by law; (5) if the law allows closed shops; (6) if workers, or unions, or both have a right to appoint members to the Boards of Directors; and (7) if workers' councils are mandated by law. 
But it can also mean that the level of social dialogue is weak and workers do have to use a power struggle to obtain by demonstrating what they would have obtained through negotiations. It may also mention social tensions in the country. This ambivalent nature of trade union rights outcome variables cannot be avoided. The task to obtain a good proxy of trade union rights is thus difficult. We will take into account this difficulty in our empirical strategy.

However, the observation of the variables coordinates on the different axis may help us to distinguish these different aspects (Table 2). As we can see, the coordinates on the first factor may be interpreted as a proxy of trade union rights and the intensity of trade unions activities. The number of strikes, of workers involved influences positively the coordinates on this factor. The civil rights index has the opposite influence (a high value of this index reflects a weak enforcement of these rights) while the index of Botero, Djankov, La Porta, and Lopez-De-Silanes (2004) has the opposite effects (more collective bargaining rights induce a positive coordinates on the first axis). We will then use the coordinates on this axis as a first proxy of trade union rights.

It is difficult to give a meaning to the second factor because of contradictory information. If workers involved in trade unions activities have a negative influence on its coordinate on this axis, the number of strikes has the opposite effect. We have the same contradiction with the two other indexes which have both positive coordinates while the meaning is the opposite. We will thus do not exploit this index.

However, the third axis gives interesting intuitions. Here, workers involved, strikes and low civil rights have a positive influence on the coordinates while the level of collective bargaining rights has a negative influence. We will thus interpret this axis as a proxy of "social tensions" for positive coordinates on this axis and "social dialogue" for negative coordinates. Countries may have very low number of strikes and workers involved if social dialogue is strong and trade union rights respected. At the contrary, numerous strikes or workers involved may be interpreted as a signal of social tensions. As we can see in Table 1 , the contribution of this axis is very closed to the one of the second axis (0.23 against 0.24$)$. We call index_TU_4 this index.

By interpreting factor 1 and 3, we use more than $55 \%$ of the information included in the variables.

Because of the difficulty to measure effectively the level of trade union rights, we propose to use in the empirical sections different alternative indexes. Two of them are constructed with the same methodology as index_TU. The three others are proposed by other authors (Botero, Djankov, La Porta, and Lopez-DeSilanes, 2004; Kucera, 2004; CEPII, 2001). 
Table 2: Coordinates of Variables on Main Factors

\begin{tabular}{lrrrr}
\hline Variable & Factor 1 & Factor 2 & Factor 3 & Factor 4 \\
\hline workers involved & 0.5676 & -0.1553 & 0.5561 & 0.5869 \\
Civil Rights Freedom House & -0.4619 & 0.7205 & 0.1502 & 0.4950 \\
Strikes & 0.4975 & 0.6384 & 0.2374 & -0.5371 \\
index_col_barg13 (BотеRo et al., 2004) & 0.4658 & 0.2217 & -0.7822 & 0.3493 \\
\hline
\end{tabular}

The index index_TU_2 aggregates the unionization rate, the number of strikes per year, the number of workers involved in trade unions activities (in \% of the working force), and the index civil rights, from Freedom House. We do not include index_col_barg13 in order to have only variables measuring the outcome of trade union rights and not legal indexes. As stated before, the main limit of this index is the limited number of countries for which we can compute this index because of limited statistics concerning unionization rate. Table 3 presents the results of PCA.

Table 3: PCA results for index_TU_2

\begin{tabular}{|c|c|c|c|c|c|}
\hline Component & Eigenvalue & Difference & \multicolumn{2}{|c|}{ Proportion } & Cumulative \\
\hline Factor 1 & 1.76356 & 0.622041 & \multicolumn{2}{|c|}{0.4409} & 0.4409 \\
\hline Factor 2 & 1.14151 & 0.491461 & \multicolumn{2}{|c|}{0.2854} & 0.7263 \\
\hline Factor 3 & 0.650054 & 0.205177 & \multicolumn{2}{|c|}{0.1625} & 0.8888 \\
\hline Factor 4 & 0.444876 & & \multicolumn{2}{|c|}{0.1112} & 1 \\
\hline \multicolumn{2}{|l|}{ Variable } & Factor 1 & Factor 2 & Factor 3 & Factor 4 \\
\hline \multicolumn{2}{|l|}{$T U \_$rate } & 0.5406 & -0.3376 & 0.6636 & -0.3917 \\
\hline \multicolumn{2}{|c|}{ workers involved } & 0.6162 & 0.2767 & 0.0719 & 0.7339 \\
\hline \multicolumn{2}{|c|}{ Civil Rights Freedom House } & -0.5327 & 0.3108 & 0.7439 & 0.2572 \\
\hline \multicolumn{2}{|l|}{ Strikes } & 0.2103 & 0.8443 & -0.0321 & -0.4919 \\
\hline
\end{tabular}

As for index_TU, the first axis would reflect the general level of trade union rights while the second axis will be interpreted as a proxy of social tensions in the country. 
We then propose to build a third index without the unionization rate (to include more countries) and without index_col_barg13 (in order to have an outcome index). Table 4 gives the result for this index index_TU_3.

Table 4: Results of PCA (index_TU_3)

\begin{tabular}{lcccc}
\hline Component & Eigenvalue & Difference & Proportion & Cumulative \\
\hline Factor 1 & 1.18537 & 0.159728 & 0.3951 & 0.3951 \\
Factor 2 & 1.02564 & 0.236653 & 0.3419 & 0.7370 \\
Factor 3 & 0.788989 & & 0.2630 & 36526 \\
\hline Variable & Factor 1 & Factor 2 & \multicolumn{2}{c}{ Factor 3 } \\
\hline workers involved & 0.7295 & -0.0141 & 0.6838 \\
Civil Rights Freedom House & -0.4490 & 0.7443 & 0.4944 \\
Strikes & 0.5159 & 0.6677 & -0.5366 \\
\hline
\end{tabular}

The fourth index is the one created by Botero, Djankov, La Porta, and LopezDe-Silanes (2004), index_col_barg13, which measures the statutory protection and power of unions. This index is clearly a legal index measuring only the legal protection of trade unions. It is included as a variable in the index_TU.

The fifth index is proposed by CEPII (2001) from a database built by researchers from the French Ministry for the Economy, Industry and Employment (MINEIE) and the French Development Agency (AFD), constructed from a world survey conducted with MINEIE and AFD agencies present in the countries covered in the database. The variable used, freedom of association, is coded from 0 to $4^{7}$.

And lastly, we will use the index proposed by KucERa (2004). His method is based on coding violations of these rights recorded in what are regarded as the three best existing textual sources on trade union rights (the International Confederation of Free Trade Unions' (ICFTU) Annual Survey of Violations of Trade Union Rights, the United States State Department's Country Reports on Human Rights Practices, and the ILO's Report of the Committee on Freedom of Association).

70 if no rights guaranteeing freedom of association - if rights exist, from $1=$ weak rights, little freedom to $4=$ strong rights, substantial freedom. 


\section{Empirical Analysis: Trade Union Rights and Migration}

\subsection{Empirical Specification and Data}

We want to measure the influence of freedom of association and collective bargaining on bilateral migration flows, by skill-level. We then propose to estimate the following models:

$$
\begin{aligned}
E M I_{i, j}^{\text {prim }} & =\alpha_{1}^{\text {prim }} L S_{i}+\alpha_{2}^{\text {prim }} X_{i}+\alpha_{3}^{\text {prim }} X_{j}+\alpha_{4}^{\text {prim }} X_{i, j}+A_{i}+A_{j}+\varepsilon_{i, j}, \\
E M I_{i, j}^{\text {sec }} & =\alpha_{1}^{\text {sec }} L S_{i}+\alpha_{2}^{\text {sec }} X_{i}+\alpha_{3}^{\text {sec }} X_{j}+\alpha_{4}^{\text {sec }} X_{i, j}+A_{i}+A_{j}+\varepsilon_{i, j}, \\
E M I_{i, j}^{\text {ter }} & =\alpha_{1}^{\text {ter }} L S_{i}+\alpha_{2}^{\text {ter }} X_{i}+\alpha_{3}^{\text {ter }} X_{j}+\alpha_{4}^{\text {ter }} X_{i, j}+A_{i}+A_{j}+\varepsilon_{i, j}
\end{aligned}
$$

where $E M I_{i, j}^{e}$ is the migration rate (in percentage of the working force of the country $i$ ) in $\log$, from country $i$ to country $j$, for workers with skill level $e$ (respectively primary, secondary or tertiary), $L S_{i}$ is the level of collective bargaining in country $i, X_{i}$ is a vector of control variables specific to the country $i, X_{j}$ is a vector of control variables specific to the country $j, X_{i, j}$ is a vector of bilateral control variables, and $A_{j}$ are the fixed effects respectively in origin and destination countries. This fixed effects measure all unobservable country characteristics that may influence the utility of migrants and thus their migratory behavior. We assume that these country characteristics are not skill-specific, ie. they influence indistinctly skilled and unskilled workers. We assume that all other variables have distinct effects of workers with different skill. That's why the coefficients $\alpha_{1,2, \ldots, 4}^{e}$ (with e alternatively prim, sec, or ter) may differ. $\varepsilon_{i, j}$ is the error term. We assume it to be i.i.d.. Standard errors are clustered at the origin-destination level and robust to heteroscedasticity (for OLS estimates).

All estimations firstly use OLS estimators and standard errors are clustered at the origin-destination-couple-level ${ }^{8}$. However, we should take into account one important feature of our migration database which is the high proportion of zero for the dependent variable ( $26 \%$ in the total population database) that may lead to inconsistent estimates. The use of a log specification will drop all

8 We do not present however the results of OLS estimate. Results are relatively similar to the one using Heckman two-steps procedures. Moreover, the inverse Mills ratio is significant in most estimations, putting in evidence biased OLS estimates. Tables of results are available upon request. 
zero observations creating biased estimates. This problem has often be ignored in the literature on migration while it is relatively common in the international trade literature (LiNDERS and DE GROOT, 2006). Some recent papers on migration deals with the high proportion of zero and propose econometric strategies to correct this biais (Beine, Docquier and Ozden, 2009; El Yaman, Kugler, and Rapoport, 2007). We thus propose to use Heckman (1979) two-step regressions providing consistent estimates in the case of selection bias. The first step is a probit estimate of the probability to have a positive migration flow (selection equation). Estimations using HecKman two steps strategy generally propose an additional instrument for this selection equation. However, as stressed by WOOLDRIDGE (2002), the use of an additional instrument in the selection equation is not strictly necessary. As it is very difficult to find a convincing instrument which may explain the decision to migrate but not influence the size of migration. we decide to run two-steps Heckman estimates without additional instrument?

Data on migration are from Docquier, Marfouk and Lowell (2007) and are available for 1991 and $2001^{10}$. Due to the small number of period, we do not include time or country fixed effects ${ }^{11}$. The measurement of trade union rights is the average over the period.

Control variables include the level of GDP per capita in origin and destination country (in $\log$ ). This variable can be interpreted in two ways. It may be a proxy of wages. It is also a proxy of migration costs. If income is too low, workers do not have the capacity to migrate. We also add the proportion of young people within the population considering this is the more mobile group (with less migratory costs). We take into account the level of democracy, measured by a combined polity score (Polity IV) proposed by GLEDITSCH $(2003)^{12}$ to capture

9 As noticed by Wooldridge (2002), the problem to not use an additional instrument is the high correlation between the Mills ratio and the other variables in the second equation. This will lead to a lower significance of the coefficients.

10 This database gives estimates of stocks of migrants and not flows. We thus estimate determinants of migrants' stocks and not flows. BRÜCKER and SCHRÖDER (2006) showed that empirical migration models estimating net migration flows instead of stocks may be misspecified: at the equilibrium, a positive relation exists between the stock of migrants while the net migration flow becomes zero. This is consistent with stylized facts that show that net migration rates tend to cease over time.

11 To test the robustness of the results, we ran estimates respectively for 1991 and for 2001 only. Results are similar despite of a lower number of observations. These results for each year are available upon request.

12 See Gleditsch and Ward (1997) for a detailed presentation of the index. Basically, this is a combined index of several sub-dimension measuring different aspects of 'authority' (competitiveness of political participation, regulation of political participation, competitiveness of 
migration costs linked to the political system. We also control for the population in origin and destination countries. We add bilateral variables such as the existence of common frontiers, distance between countries, the fact to have a common language, and the fact to have a past colonial past. All these variables are correlated with the existence of a network of migrants and then will influence the migratory costs. Finally, we also add regional dummies in order to capture partially unobserved heterogeneity between countries.

Because of the lack of temporal data, we face several problems in the first set of estimations. We cannot control for unobserved country characteristics in origin countries. One cannot exclude an omitted variable bias (even if we control with the variables traditionally defined as the main determinants of migration). Also, in destination countries, we choose to use destination countries dummies in order to capture these unobserved characteristics. However, variables $X_{j}$ are dropped in the estimations. But our goal here is to measure the effects of trade unions rights in origin countries, so it is not a problem here.

One solution to deal with this possible omitted variable bias is to estimate the differences of effects between workers with different skills. We saw in the theoretical section that we may expect an effect on low-skilled and high-skilled workers. We thus propose to estimate the differences of migration rate between these two categories of workers and intermediary-skilled workers. More precisely, the estimated equations will be:

$$
\begin{aligned}
E M I_{i, j}^{\text {prim }}-E M I_{i, j}^{\text {sec }} & =\left(\alpha_{1}^{\text {prim }}-\alpha_{1}^{\text {sec }}\right) L S_{i}+\left(\alpha_{2}^{\text {prim }}-\alpha_{2}^{\text {sec }}\right) X_{i} \\
& +\left(\alpha_{3}^{\text {prim }}-\alpha_{3}^{\text {sec }}\right) X_{j}+\left(\alpha_{4}^{\text {prim }}-\alpha_{4}^{s e c}\right) X_{i, j}+\varepsilon_{i, j} \\
E M I_{i, j}^{\text {ter }}-E M I_{i, j}^{\text {sec }} & =\left(\alpha_{1}^{\text {ter }}-\alpha_{1}^{\text {sec }}\right) L S_{i}+\left(\alpha_{2}^{\text {ter }}-\alpha_{2}^{s e c}\right) X_{i} \\
& +\left(\alpha_{3}^{\text {ter }}-\alpha_{3}^{\text {sec }}\right) X_{j}+\left(\alpha_{4}^{\text {ter }}-\alpha_{4}^{\text {sec }}\right) X_{i, j}+\varepsilon_{i, j}
\end{aligned}
$$

Here, we do not estimate the determinants of migration by skill-level but the differences of effects according to the skill-level. As the unobserved country-characteristics $\left(A_{i}\right.$ and $\left.A_{j}\right)$ are supposed to be independent of the skill-level of workers, they are dropped when we estimate the differences. The omitted variable bias thus disappear in this new set of estimations.

executive recruitment, openness of executive recruitment, constraints on chief executive). It is included between -10 (autocracy) and 10 (democracy). 


\subsection{Results}

Table 5 gives the result of the estimations using our first index of trade union rights (index_TU). We observe a significant and negative relation between trade union rights and emigration rates. This effect on the overall migration flows is explained by a significant impact on the emigration rate of primary educated workers and tertiary educated workers. Our two models presented in the theoretical section of this paper are then validated conjointly by our estimates. Lowskilled workers may benefit from trade union rights through an increased bargaining power, higher wages and better working conditions. On the other side, high-skilled workers may also benefit from trade union rights because of a wage premium in the formal sector. Effects are not significant for secondary educated workers for whom one effect may be compensated by the other.

Other control variables globally take the expected sign. The GDP per capita in origin countries has a negative influence on emigration rate, except for lowskilled workers where this variable is not significant. This can be explained by the existence of too high migration costs for this category of workers. Population in origin countries is negatively correlated with emigration rates while population in destination countries has a positive influence. Political factors seem to have a significant role: autocracy increases migration costs. However, this effect is not significant for skilled workers. Concerning bilateral variables, only the fact to have a former colonial relationship has a significant (and positive) impact on bilateral migration flows. However, we may suppose that the effect of other variables (such as the common language) is also captured by this variable.

This first result is important. For different reasons, trade union rights may retain both low-skilled and high-skilled workers. We should however be cautious at this stage in the interpretation of our results. First, we should not underestimate the possible ommited variable bias because of the impossibility to control for unobserved country-characteristics in origin countries. That's why we propose to estimate the differences of effects between workers with different skilllevel (equation 10 and 11). Second, we should take into account the difficulty to measure effectively trade union rights. That is why we propose to test, in the following section, the robustness of these results by using alternative indexes of trade union rights, presented in the previous section.

We then estimate equations 10 and 11 . As unobserved country characteristics are supposed to have similar effects on workers with different skill-level, we do not include origin or destination fixed effects. However, we do take into account some characteristics of destination countries that may have distinct effect according to the skill-level (variables included in the matrix $X_{j}$ ). In particular, the GDP 


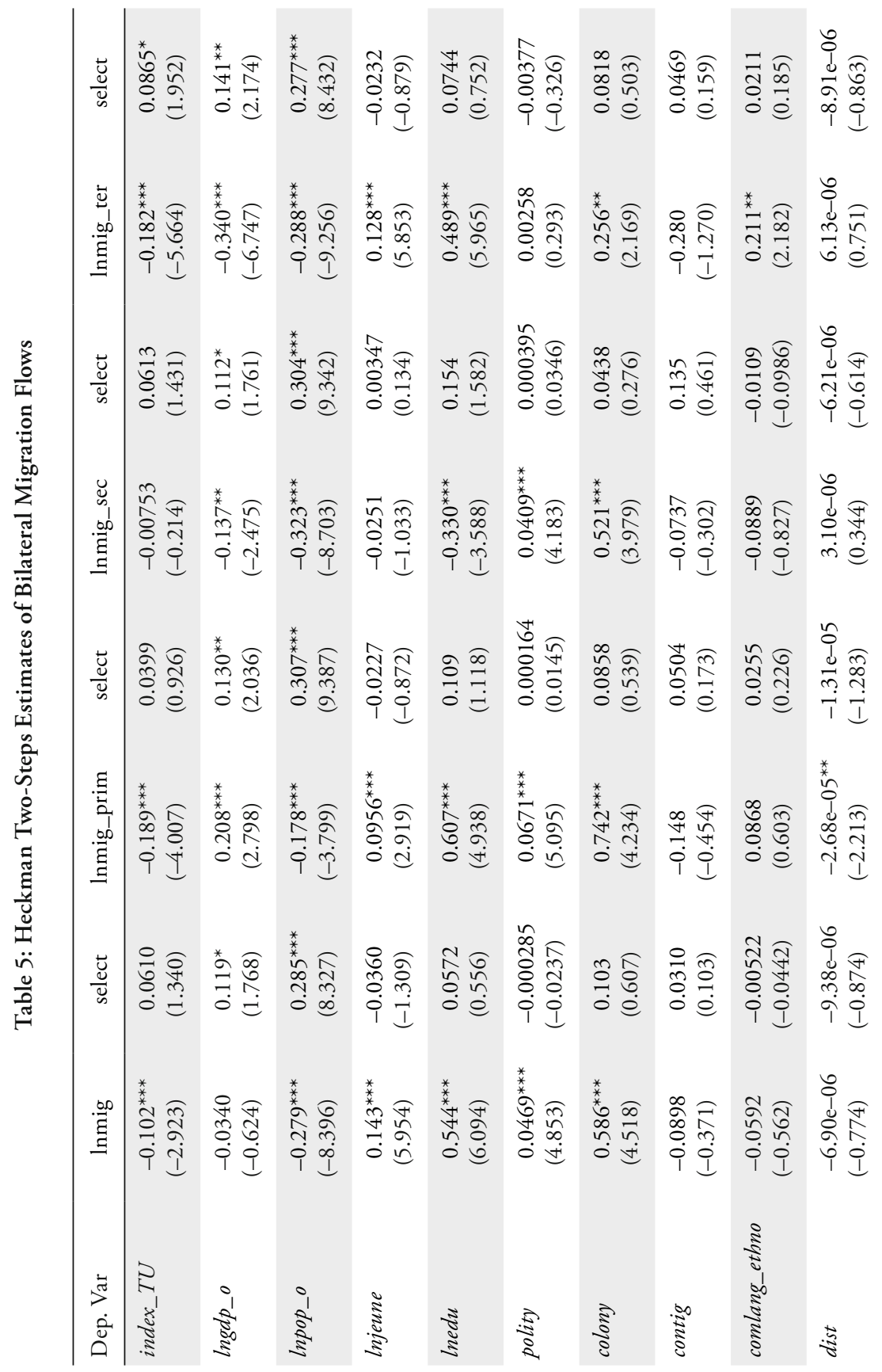




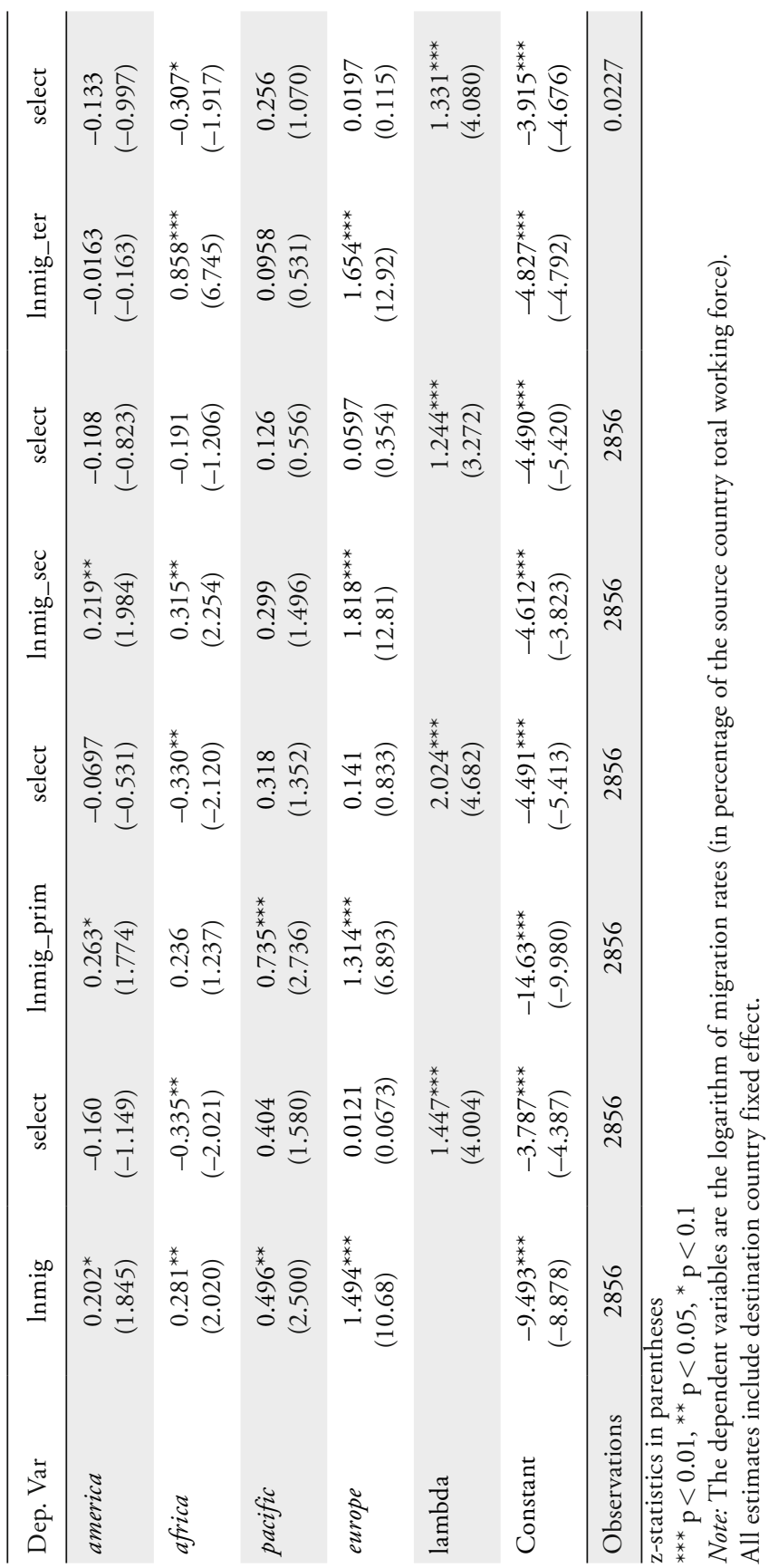


Table 6: Differences of Effects between Primary and Secondary Skilled-Workers and between Tertiary and Secondary Skilled-Workers

\begin{tabular}{|c|c|c|c|c|}
\hline Dep. Var & Diff (Prim-Sec) & select & Diff (Ter-Sec) & select \\
\hline index_TU & $\begin{array}{l}-0.185^{* * *} \\
(-7.833)\end{array}$ & $\begin{array}{c}0.0272 \\
(0.735)\end{array}$ & $\begin{array}{l}-0.158^{* * *} \\
(-5.812)\end{array}$ & $\begin{array}{c}0.0548 \\
(1.449)\end{array}$ \\
\hline $\operatorname{lng} d p_{-} o$ & $\begin{array}{l}0.299^{* * *} \\
(7.888)\end{array}$ & $\begin{array}{c}0.102^{*} \\
(1.840)\end{array}$ & $\begin{array}{l}-0.194^{* * *} \\
(-4.507)\end{array}$ & $\begin{array}{l}0.113^{* *} \\
(2.009)\end{array}$ \\
\hline $\ln g d p \_d$ & $\begin{array}{c}0.126 \\
(0.731)\end{array}$ & $\begin{array}{l}1.564^{* * *} \\
(20.81)\end{array}$ & $\begin{array}{l}0.785^{* * *} \\
(4.454)\end{array}$ & $\begin{array}{l}1.505^{* * *} \\
(19.99)\end{array}$ \\
\hline lnpop_o & $\begin{array}{c}0.0421 \\
(1.462)\end{array}$ & $\begin{array}{l}0.257^{* * *} \\
(9.204)\end{array}$ & $\begin{array}{l}0.110^{* * *} \\
(3.560)\end{array}$ & $\begin{array}{l}0.253^{* * *} \\
(8.975)\end{array}$ \\
\hline lnpop_d & $\begin{array}{l}0.109^{* * *} \\
(7.520)\end{array}$ & $\begin{array}{l}0.0489^{* *} \\
(2.312)\end{array}$ & $\begin{array}{l}0.177^{* * *} \\
(11.42)\end{array}$ & $\begin{array}{c}0.0161 \\
(0.746)\end{array}$ \\
\hline Injeune & $\begin{array}{l}0.126^{* * *} \\
(6.550)\end{array}$ & $\begin{array}{l}-0.0939^{* * *} \\
(-4.114)\end{array}$ & $\begin{array}{l}0.116^{* * *} \\
(5.573)\end{array}$ & $\begin{array}{l}-0.0859^{* * *} \\
(-3.720)\end{array}$ \\
\hline $\ln e d u$ & $\begin{array}{l}0.886^{* * *} \\
(14.02)\end{array}$ & $\begin{array}{c}0.118 \\
(1.400)\end{array}$ & $\begin{array}{l}0.862^{* * *} \\
(12.35)\end{array}$ & $\begin{array}{c}0.100 \\
(1.175)\end{array}$ \\
\hline polity & $\begin{array}{l}0.0265^{* * *} \\
(4.010)\end{array}$ & $\begin{array}{l}-0.00127 \\
(-0.129)\end{array}$ & $\begin{array}{l}-0.0348^{* * *} \\
(-4.678)\end{array}$ & $\begin{array}{l}-0.00114 \\
(-0.115)\end{array}$ \\
\hline colony & $\begin{array}{c}0.152^{*} \\
(1.727)\end{array}$ & $\begin{array}{c}0.160 \\
(1.122)\end{array}$ & $\begin{array}{l}-0.209^{* *} \\
(-2.086)\end{array}$ & $\begin{array}{c}0.120 \\
(0.843)\end{array}$ \\
\hline contig & $\begin{array}{l}-0.344^{* *} \\
(-2.146)\end{array}$ & $\begin{array}{c}0.0324 \\
(0.126)\end{array}$ & $\begin{array}{l}-0.203 \\
(-1.104)\end{array}$ & $\begin{array}{c}0.0569 \\
(0.221)\end{array}$ \\
\hline comlang_ethno & $\begin{array}{l}0.224^{* * *} \\
(3.090)\end{array}$ & $\begin{array}{c}0.0193 \\
(0.197)\end{array}$ & $\begin{array}{l}0.280^{* * *} \\
(3.449)\end{array}$ & $\begin{array}{l}-0.0223 \\
(-0.227)\end{array}$ \\
\hline dist & $\begin{array}{l}-2.35 \mathrm{e}-05^{* * *} \\
(-3.862)\end{array}$ & $\begin{array}{l}-8.12 \mathrm{e}-06 \\
(-0.918)\end{array}$ & $\begin{array}{l}2.50 \mathrm{e}-06 \\
(0.364)\end{array}$ & $\begin{array}{l}-5.37 \mathrm{e}-06 \\
(-0.599)\end{array}$ \\
\hline america & $\begin{array}{c}0.0914 \\
(1.229)\end{array}$ & $\begin{array}{l}-0.0105 \\
(-0.0928)\end{array}$ & $\begin{array}{l}-0.252^{* * *} \\
(-2.986)\end{array}$ & $\begin{array}{l}-0.0628 \\
(-0.546)\end{array}$ \\
\hline africa & $\begin{array}{c}0.000543 \\
(0.00561)\end{array}$ & $\begin{array}{c}-0.174 \\
(-1.290)\end{array}$ & $\begin{array}{l}0.522^{* * *} \\
(4.897)\end{array}$ & $\begin{array}{l}-0.134 \\
(-0.976)\end{array}$ \\
\hline pacific & $\begin{array}{l}0.335^{* *} \\
(2.467)\end{array}$ & $\begin{array}{c}0.157 \\
(0.785)\end{array}$ & $\begin{array}{l}-0.132 \\
(-0.859)\end{array}$ & $\begin{array}{c}0.210 \\
(1.013)\end{array}$ \\
\hline europe & $\begin{array}{l}-0.487^{* * *} \\
(-5.088)\end{array}$ & $\begin{array}{c}0.153 \\
(1.048)\end{array}$ & $\begin{array}{l}-0.112 \\
(-1.038)\end{array}$ & $\begin{array}{c}0.0645 \\
(0.437)\end{array}$ \\
\hline lambda & & $\begin{array}{l}-0.395 \\
(-1.409)\end{array}$ & & $\begin{array}{l}1.102^{* * *} \\
(3.792)\end{array}$ \\
\hline Constant & $\begin{array}{c}-10.35^{* * *} \\
(-4.207)\end{array}$ & $\begin{array}{l}-21.13^{* * *} \\
(-18.16)\end{array}$ & $\begin{array}{c}-13.22^{* * *} \\
(-5.326)\end{array}$ & $\begin{array}{l}-19.88^{* * *} \\
(-17.10)\end{array}$ \\
\hline Observations & 2856 & 2856 & 2856 & 2856 \\
\hline
\end{tabular}

Please observe the legend at the bottom of page 697. 
level and the population in destination countries are used as additional control variables. Results are given in Table 6.

In these estimations, trade union rights have a negative impact on the migration of low-skilled workers compared to the migration of intermediary skilled workers. As the estimation in difference drop the possible omitted variable bias, we can say that model $a$ is validated by these data. According to this model, trade union rights are equivalent to a transfer towards low-skilled workers which lower their incentive to migrate. At the same time, trade union rights also reduce the migration of tertiary-skilled workers compared to workers with intermediate skills. This tends to confirm the intuition presented in the model $b$. In this model, trade union rights improve the conditions of formal workers who are relatively more educated. This will reduce their incentive to migrate. As we can see, trade union rights tends to have similar effects for low-skilled and high-skilled workers but the explanations of such effects are completely different. The losers of an improvement of trade union rights will be workers with intermediate skills.

\subsection{Robustness Checks of the Results: Alternative Indexes of Trade Union Rights}

We only present the estimated coefficient of different trade union rights indexes. Estimated coefficients of control variables are globally similar with the results presented in Table 5.

Both legal indexes and outcome indexes confirm the previous result: trade union rights has a negative impact on bilateral migration flows both for primary educated workers and tertiary educated workers ${ }^{13}$. The only difference is the result obtained with the index of trade union rights violations proposed by KUCERA (2004). The result is inverted. Less violations of these rights would increase the migration rate, both for primary and tertiary educated workers.

13 We should notice however some slight differences when using Index_TU_1 and Index_TU_2. In the first case, coefficient is negative and significant for tertiary and secondary educated workers, but not for primary-educated workers. For Index_TU_2, coefficients for primary and secondary educated workers are negative but not significant. These differences can be explained by a lower number of observations (for index_TU_1).

$\leftarrow$ z-statistics in parentheses

${ }^{* * *} \mathrm{p}<0.01,{ }^{* *} \mathrm{p}<0.05,{ }^{*} \mathrm{p}<0.1$

Note: Dependant variables are the differences between the logarithm of migration rates (in percentage of the source country total working force) of primary and secondary-skilled workers (columns 1 and 2); and tertiary and secondary-skilled workers (colums 3 and 4). 


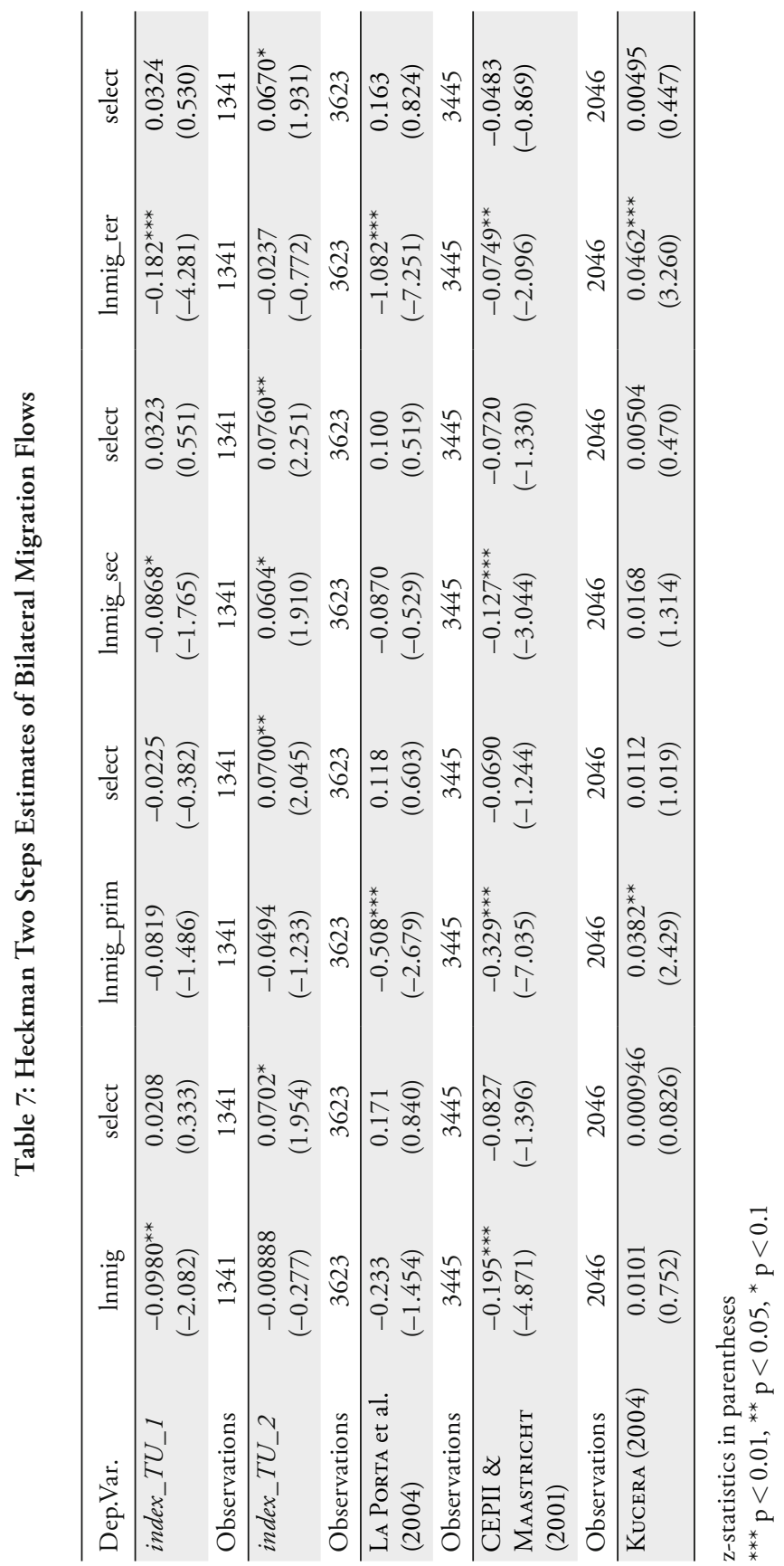


Table 8: Differences between Skill-Levels

\begin{tabular}{lcccc}
\hline Dep.Var. & $\begin{array}{c}\text { Diff } \\
(\text { Prim-Sec) }\end{array}$ & select & Diff (Ter-Sec) & select \\
\hline index_TU_1 & -0.0100 & -0.00170 & -0.0784 & 0.0252 \\
& $(-0.287)$ & $(-0.0332)$ & $(-1.492)$ & $(0.482)$ \\
Observations & 1341 & 1341 & 1341 & 1341 \\
\hline index_TU_2 & $-0.112^{* * *}$ & $0.0588^{* *}$ & -0.0468 & $0.0629^{* *}$ \\
& $(-5.533)$ & $(2.027)$ & $(-1.483)$ & $(2.141)$ \\
Observations & 3623 & 3623 & 3623 & 3623 \\
\hline LA PorTA et al. (2004) & $-0.575^{* * *}$ & -0.0312 & $-1.042^{* * *}$ & -0.0144 \\
& $(-5.260)$ & $(-0.185)$ & $(-8.736)$ & $(-0.0848)$ \\
Observations & 3445 & 3445 & 3445 & 3445 \\
\hline CEPII \& MaAsTRICHT (2001) & $-0.196^{* * *}$ & -0.0350 & $0.0562^{*}$ & -0.0488 \\
& $(-6.523)$ & $(-0.765)$ & $(1.682)$ & $(-1.071)$ \\
Observations & 2046 & 2046 & 2046 & 2046 \\
\hline KucERA (2004) & $0.0201^{* *}$ & 0.0139 & $0.0322^{* * *}$ & 0.00615 \\
& $(2.532)$ & $(1.488)$ & $(3.577)$ & $(0.656)$ \\
Observations & 5241 & 5241 & 5241 & 5241 \\
\hline
\end{tabular}

z-statistics in parentheses

${ }^{* * *} \mathrm{p}<0.01,{ }^{* *} \mathrm{p}<0.05,{ }^{*} \mathrm{p}<0.1$

Estimations of equation 10 and 11 with alternative indexes of trade union rights also globally confirmed the results presented in the previous section. Estimated coefficients always have the same sign except for tertiary-educated workers when using the index CEPII \& Maastrich. We also have the opposite effect when using the Kucera index. The following section will give an explanation to this apparent contradiction.

\section{Migration, Social Tensions and Social Dialogue}

As we saw in section III, outcome variables may reflect two things: (1) the level of trade union rights which we measure through our index index_TU, but also (2) the level of social tensions which is captured by the third factor of the PCA (index_TU_4). As we can see in Figure 1, different profiles of countries can be detected.

Countries such as Argentina or Bolivia for example are characterized by a high value of their coordinates on the first and second axis. This can be interpreted by 
a high level of social tensions. For relatively similar coordinates on the first axis, countries such as Sweden, Norway or Japan have a negative coordinates on the second axis. This is a characteristic of countries where level of social dialogue is high and thus, the number of strikes is limited. Until now, we only focused on trade union rights. But we can suppose that social tensions may have different effects. Violations of trade union rights measured by KUCERA (2004) may also be linked to this level of social tensions. Violations of these rights are of course negatively correlated with their respect. But it may also be positively correlated with the general level of social tensions in the country. We then propose to measure the influence of this aspect in the migration decision, by estimating conjointly the effect of trade union rights as such through index_TU, and the effect of social tensions measured by index_TU_4 and Kucera index.

The results confirm this intuition (Table 9). If trade union rights still have a negative impact on migration (index_TU), our index index_TU_4 which is a proxy of social tensions has the opposite effect. We find the same result when we use the Kucera index of trade union rights violations. The only difference is the positive sign is significant for primary educated workers when we use the Kucera index while it is significant for tertiary-educated workers when we use Index_TU_4. The sign and the significance of both coefficients are similar when these indexes are integrated conjointly in the specification.

These results are confirmed by the estimations of the relative effects on lowskilled and high-skilled workers (see Table 10).

Trade union rights can be an effective tool to retain workers in their country. It is interesting to notice that this result is also confirmed for high-skilled workers. Trade union rights may be a tool to fight against brain drain. However, the existence of trade union rights is not a sufficient condition for retaining workers. If the development of trade union rights came together with a development of social tensions, it can have the opposite effects. Instability is a factor of emigration. Political instability may be a factor of emigration. It is also true for social instability.

\section{Conclusions}

In this paper, we show theoretically two channels of transmission from trade union rights to migration. The first one is an increased bargaining power for workers and more especially low-skilled workers. The second one is the existence of a wage premium in the formal sector that will benefit mainly to high-skilled workers. Empirically, we propose different measures of trade union rights. We find that these rights in origin countries have a negative impact on emigration 
Figure 1: PCA Analysis of Trade Union Rights and Social Tensions

Freedom of Association - Social Dialogue - Social Tensions

PCA analysis of trade unions rights

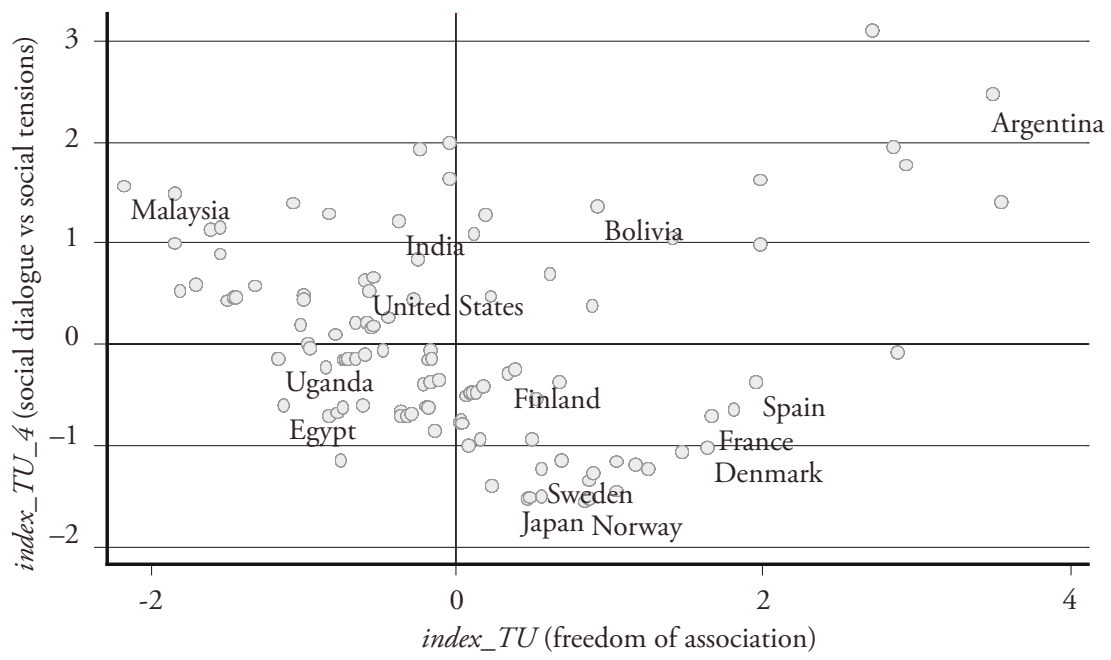

index_TU is the first axis of the PCA. Index_TU_4 is the third one.

Labels marked are for year 2001.

Note: The PCA analysis includes as variables: the number of strikes per year, the number of workers involved in trade unions activities (in \% of the working force), the index civil rights (Freedom House), and the index of Botero, Djankov, La Porta, and Lopez-De-Silanes (2004).

rates, all things being equal, for low-skilled workers and high-skilled workers. Effects are not significant for secondary-educated workers. Both theoretical models are then validated by our estimates.

However, we also put in evidence that trade union rights may have heterogeneous consequences. The development of such rights may increase the level of social dialogue but it may also increase the level of organized strikes and demonstrations. As it is the case for political instability, social disorders may be a factor of emigration. The second effect may counterbalance the first one.

If the development of trade union rights may be seen as a political instrument for retaining workers in their home country, and particularly for avoiding brain drain, the government should also propose a framework favorable to the development of social dialogue and non-confrontational collective bargaining mechanisms. 


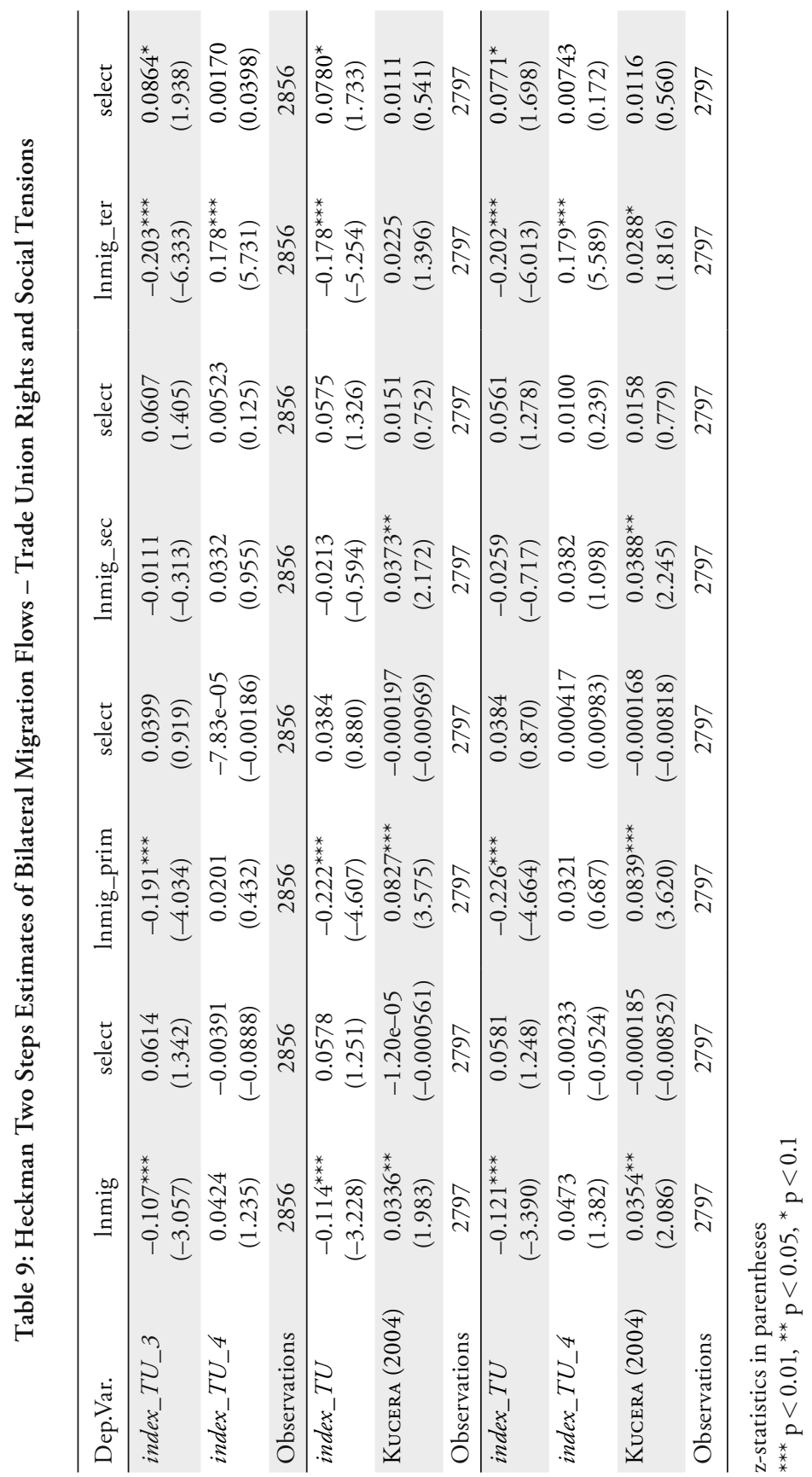


Table 10: Differences of Effects

\begin{tabular}{lcccc}
\hline Dep.Var. & Diff $($ Prim-Sec) & select & Diff $(\mathrm{Ter}-\mathrm{Sec})$ & select \\
\hline index_TU & $-0.185^{* * *}$ & 0.0244 & $-0.177^{* * *}$ & 0.0518 \\
& $(-7.810)$ & $(0.650)$ & $(-6.665)$ & $(1.352)$ \\
index_TU_4 & 0.00366 & 0.0189 & $0.162^{* * *}$ & 0.0224 \\
& $(0.157)$ & $(0.519)$ & $(6.261)$ & $(0.609)$ \\
Observations & 2856 & 2856 & 2856 & 2856 \\
\hline index_TU & $-0.201^{* * *}$ & 0.0223 & $-0.140^{* * *}$ & 0.0491 \\
& $(-8.309)$ & $(0.596)$ & $(-4.942)$ & $(1.280)$ \\
KuCERA (2004) & $0.0407^{* * *}$ & 0.0174 & -0.0116 & 0.0175 \\
& $(3.473)$ & $(0.991)$ & $(-0.857)$ & $(0.987)$ \\
Observations & 2797 & 2797 & 2797 & 2797 \\
\hline index_TU & $-0.202^{* * *}$ & 0.0183 & $-0.161^{* * *}$ & 0.0446 \\
& $(-8.298)$ & $(0.480)$ & $(-5.955)$ & $(1.143)$ \\
index_TU_4 & 0.0100 & 0.0240 & $0.158^{* * *}$ & 0.0287 \\
& $(0.425)$ & $(0.654)$ & $(6.064)$ & $(0.772)$ \\
KucERA (2004) & $0.0410^{* * *}$ & 0.0191 & -0.00629 & 0.0195 \\
& $(3.489)$ & $(1.071)$ & $(-0.488)$ & $(1.086)$ \\
Observations & 2797 & 2797 & 2797 & 2797 \\
\hline
\end{tabular}

z-statistics in parentheses

${ }^{* * *} \mathrm{p}<0.01,{ }^{* *} \mathrm{p}<0.05,{ }^{*} \mathrm{p}<0.1$

\section{References}

Aidt, T., and Z. Tzannatos (2002), "Unions and Collective Bargaining: Economic Effects in a Global Environment", Directions in Development Series, The World Bank, Washington D.C.

Bazillier, R. (2008), "Core Labour Standards and Economic Development: Impact on Longterm per-capita Income", World Development, 36 (1), pp. 17-39.

Bazillier, R. and N. Sirven (2008), "Core Labour Standards and Inequalities, Is there a Social Kuznets Curve?”, Journal of Development Studies, 44 (7), pp. 913-934.

Beine, M., F. Docquier, and C. Ozden (2009), "Diasporas", World Bank Policy Research, (4984).

Beine, M., F. Docquier, and H. Rapoport (2001), "Brain Drain and Economic Growth: Theory and Evidence", Journal of Development Economics, 64(1), pp. 275-289. 
Beine, M., F. Docquier, and H. Rapoport (2003), "Brain Drain and LDC's Growth: Winners and Losers", The Institute for the Study of Labor, IZA DP No. 819.

Bhagwati, J., and W. Dellafar (1973), "The Brain Drain and Income Taxation", World Development, 1 (1-2), pp.94-101.

Bhagwati, J., and Hamada (1974), "The Brain Drain, International Integration of Markets for Professionals and Unemployment: A Theoretical Analysis", Journal of Development Economics, vol. 1, June, pp. 19-24.

BorJas, G. J. (1994), "The Economics of Immigration”, Journal of Economic Literature, vol. XXXII, December, pp. 1667-1717.

Borjas, G. J. (1999), "The Economic Analysis of Immigration", in Handbook of Labor Economics, ed. by O. Ashenfelter, and D. Card, vol.3, chap. 28, pp. 1697-1760, Amsterdam.

Borjas, G., R. Freeman, and L. Katz (1997), "How much do Immigration and Trade Affect Labor Market Outcomes", Brookings Papers on Economic Activity, 1, pp. 1-67.

Botero, J., S. Djankov, R. La Porta, and F. C. Lopez-De-Silanes (2004), "The Regulation of Labor", The Quarterly Journal of Economics, 119 (4), pp. 1339-1382.

Brown, D. K. (2000), "International Trade and Core Labour Standards: A Survey of the Recent Literature", OECD Labour Market and Social Policy Occasional Papers 43, OECD, Directorate for Employment, Labour and Social Affairs.

Brown, D., A. Deardorff, and R. Stern (1996), "International Labour Standards and Trade: A Theoretical Analysis", in: J. Bhagwati and R. Hudec (eds), Fair Trade and Harmonization: Prerequisities for Free Trade?, pp. 227-280. MA: Cambridge.

BrÜCKer, H., and P. J. H. Schröder (2006), "International Migration with Heterogeneous Agents: Theory and Evidence", IZA Discussion Papers 2049, Institute for the Study of Labor (IZA).

Calvo, G. (1978), "Urban Employment and Wage Determination in LDC's: Trade Unions in the Harris-Todaro Model", International Economic Review, 19 (1), pp. 65-81.

CEPII (2001), Institutional Profiles Database (IPD).

Defoort, C. (2008), «Tendance de long terme des migrations internationales, analyse a partir des 6 principaux pays receveurs», Population, 63 (2), pp.317-361.

Docquier, F., A. Marfouk, and B. L. Lowell (2007), "A Gender Assessment of the Brain Drain", dataset 1990-2000 with gender breakdown (Rel.2.1). 
El Yaman, O., M. Kugler, and H. Rapoport (2007), "Migrations et investissements directs étrangers dans l'espace européen», Revue Economique, (58 2007/3), pp. 725-733.

Fields, G. (1975), "Rural-Urban Migration, Urban Unemployment and Underemployment and Job Search Activity in LDC's", Journal of Development Economics, vol.2, pp. 165-187.

Freedom House (2005), "Annual Survey of Freedom Country Score", www. freedomhouse.org.

GhaI, D. (2003), "Decent Work: Concepts and Indicators", International Labour Review, 142 (2), pp. 121-157.

Gleditsch, K. S., and M. Ward (1997), "A Re-Examination of Democracy and Autocracy in Modern Politics", Journal of Conflict Resolution, 41 (3), pp.361-383.

Gleditsch, K. S. (2003), "Modified Polity P4 and P4D Data", Version 1.0. URL: http://weber.ucsd.edu/kgledits/Polity.htm.

Granger, C. (2005), «Normes de travail fondamentales et échanges Sud-Nord», Economie Internationale, 101, pp. 47-62.

Grossman, J. (1982), "The Substitutability of Natives and Immigrants in Production", Review of Economics and Statistics, 54 (4), pp. 596-603.

Gupta, M. R. (1993), "Rural-Urban Migration, Informal Sector, and Development Policies", Journal of Development Economics 41 (1).

Harris, J. R., and M. P. Todaro (1970), "Migration, Unemployment and Development: A Two Sector Analysis", American Economic Review, 60, pp. 126-142.

Harrison, A., and E. Leamer (1997), "Labor Markets in Developing Countries: An Agenda for Research", Journal of Labor Economics, 15 (3), pp. 1-19.

Heckman, J. J. (1979), "Sample Selection Bias as a Specification Error", Econometrica, 47 (1), pp. 53-161.

Hicks, J. R. (1932), The Theory of Wages, London.

Jose, A. (2002), Organized Labour in the 21st century. Geneva.

Kucera, D. (2002), "Core Labour Standards and Foreign Direct Investment", International Labour Review, 141 (1-2).

Kucera, D. (2004), "Measuring Trade Union Rights: A Country-Level Indicator Constructed from Coding Textual Sources", Policy Integration Department Working Paper, International Labour Organization, 50, 2004.

Kucera, D., and R. Galli (2004), "Labor Standards and Informal Employment in Latin America”, World Development, 32 (5), pp. 809-28.

Levhari, D., and O. Stark (1982), "On Migration and Risk in Less Developed Countries", Economic Development and Cultural Change, 31. 
Lindbeck, A., and D. J. Snower (2001), "Insiders versus Outsiders", Journal of Economic Perspectives, 15 (1), pp. 165-188.

Linders, G.-J. M., and H. L. DE Groot (2006), "Estimation of the Gravity Equation in the Presence of Zero Flows", Tinbergen Institute Discussion Papers 06-072/3, Tinbergen Institute.

Màrquez, G., and C. Pagès (1998), "Ties that Bind: Employment Protection and Labor Market Outcomes in Latin America”, Inter-American Development Bank working paper, R-427. Washington, DC: IADB.

Maskus, K. (1997), "Should Core Labor Standards be Imposed Through International Trade Policy?”, World Bank Policy Research Working Paper, 1817.

Mountrord, A. (1997), "Can a Brain Drain be Good for Growth in the Source Economy?” Journal of Development Economics, 53 (2), pp. 287-303.

OECD (1996), Trade, Employement and Labour Standards: A Study of Core Worker's Right and International Trade, Paris.

OECD (2000), International Trade and Core Labour Standards, Paris.

OECD (2008), International Migration Outlook 2008, Paris.

Quibria, M. G. (1988), "Migration, Trade Unions, and the Informal Sector: A Note on Calvo", International Economic Review, Department of Economics, University of Pennsylvania and Osaka University Institute of Social and Economic Research Association, 29 (3), pp. 557-563, August.

Saint-Paul, G. (2002), "The Political Economy of Employment Protection", Journal of Political Economy, 110 (3), pp. 672-701. 6, 21.

Schiff, M. (1999), "Trade, Migration and Welfare: The Impact of Social Capital”, Policy Research Working Paper WPS 2044, World Bank.

Schiff, M. (2002), "Love Thy Neighbor: Trade, Migration, and Social Capital", European Journal of Political Economy, 18, pp. 87-107.

Singh, A., and A. Zамmiт (2000), "The Global Labour Standards Controversy: Critical Issues for Developing Countries", Geneva, Switzerland: South centre. Stark, O. (1991), The Migration of Labour, Oxford.

Stark, O., C. Helmenstein, and A. Prskawetz (1997), "A Brain Gain with a Brain Drain”, Economics Letters, 55 (2), pp. 227-234.

Stark, O., and J. E. Taylor (1991), "Relative Deprivation and Migration", Policy Research Working Paper WPS 656, World Bank.

Stark, O., and S. Yitzhaki (1988), "Migration as a Response to Relative Deprivation", Journal of Population Economics, 1.

Todaro, M. P. (1969), "A Model of Labor Migration and Urban Unemployment in Less Developed Countries", American Economic Review, 59.

Wooldridge, J. (2002), Econometric Analysis of Cross-Section and Panel Data. MIT Press, Cambridge. 


\section{SUMMARY}

We study in this paper both theoretically and empirically the influence of trade union rights in origin countries on bilateral migration flows. Theoretically, trade union rights are supposed to increase the bargaining power of workers. Alternatively, it may benefit only to formal workers if these rights are not applied in the informal sector. We then propose different alternative indexes measuring trade union rights. We find that, all things being equal, more trade union rights tend to be associated with less migration of low-skill and high-skilled workers. Effects are not significant for intermediate skill level. Lastly, we show that social tensions may have the opposite effect. If trade union rights are associated with more social instability, it may increase the level of migration. It emphasizes the importance of social dialogue. 